\title{
Identification of a Novel -99A>T IAPP Gene Mutation in A North Indian Type-2-Diabetes Patient with Hypertension
}

\author{
Jayagandan Jayamani $^{1 *}$, Rajendra Prasad ${ }^{1}$ and Anil Bhansali ${ }^{2}$ \\ ${ }^{1}$ Post Graduate Institute of Medical Education and Research, Biochemistry, Chandigarh, India \\ ${ }^{2}$ Post Graduate Institute of Medical Education and Research, Endocrinology, Chandigarh, India
}

\begin{abstract}
Several studies conducted worldwide supports that mutations in activator domains of promoter region (-91 to -222 bp) of IAPP gene can lead to increased Islet amyloid deposition, B cells destruction and insulin resistance. Considering it a pilot study was conducted to identify amylin promoter mutation and its association in patients diagnosed having both type-2-diabetes and hypertension. Strikingly we identified a novel -99A $>$ T mutation in a 35 year old female patient with BMI of $26.4 \mathrm{~kg} / \mathrm{m}^{2}$ and family history of diabetes and hypertension. To elucidate whether the identified mutation disrupts the binding site for transcription factors, potential binding sites in the vicinity of this mutation was screened for using the TESS master (Transcription Element Search System) a computer program on TRANSFAC, EMBL, CBIL databases. This -99A >T mutation produced a sequence 5'-ATTGG-3' (corresponding to -101 to -97 of IAPP gene promoter) and its complementary sequence $3^{\prime}-T A A C C-5$ ' formed a putative binding site for CAAT box binding transcription factors (CTF) like CBP, CP-1, C/EBP $\alpha$. All these CTFs are well established transcription activators, their role in initiation and maintaining efficiency of eukaryotic transcription is also very well established. This activator domain $-99 \mathrm{~A}>\mathrm{T}$ mutation of IAPP gene can possibly increase gene transcription, production, deposition of Islet amyloid ultimately leading to pathogenesis of type-2-diabetes.
\end{abstract}

\section{Case Description}

A 37-year-old North-Indian woman with type-2-diabetes mellitus was enrolled in a clinical study to establish association of promoter mutation $-132 \mathrm{G}>\mathrm{A}$ of IAPP (Amylin) gene and hypertension associated with type-2-diabetes mellitus. Patient was diagnosed having type 2 diabetes mellitus at the age of 29 years and was diagnosed having hypertension 3 weeks prior to the study enrolment. Her family history was limited to her mother having diabetes. Patient had a BMI of 26.4 $\mathrm{kg} / \mathrm{m}^{2}$ at enrolment and being treated with insulin, statins and ACEinhibitor.

The baseline investigations including blood glucose, blood urea, serum creatinine, fasting lipid profile of patient were done. Results of metabolic chemistry were within reference intervals except for increased levels of postprandial glucose (Postprandial $218 \mathrm{mg} / \mathrm{dL}$; reference interval, $<180 \mathrm{mg} / \mathrm{dL}$ ), total cholesterol $(218 \mathrm{mg} / \mathrm{dL}$; reference interval, $150-200 \mathrm{mg} / \mathrm{dL}$ ), triglycerides (445.75 mg/dL; reference interval, 50 $200 \mathrm{mg} / \mathrm{dL}$ ). The HBA1C value was $12.2 \%$ (reference interval, $<6.0 \%$ ). Patient had no micro and macro-vascular complications. All other laboratory results including serum electrolytes, serum lipoproteins, total protein, albumin, are shown in Table 1. Genomic investigation of patient was done and strikingly we identified a novel mutation $-99 \mathrm{~A}>\mathrm{T}$ in IAPP (Amylin) proximal promoter region. The mutated sequence had been submitted and published in Genbank (Genbank accession \#: KC432757).

\section{Discussion}

Islet amyloid polypeptide (IAPP) also called as Amylin is a 37 amino acid peptide is a major subunit of amyloid found in insulinomas and pancreatic islet amyloid of patients with type 2 diabetes mellitus [1]. The structural and functional feature of amylin suggests that it has a hormonal control over carbohydrate metabolism in partnership with insulin and other glucoregulatory factors. Immunolocalisation studies of its secretory granules confirmed that amylin is synthesised in, and probably co-secreted from the B-cells of the Islets of Langerhans [2]. Apart from its pathological role in type-2-diabetes [3,4], amylin also plays a vital role in glycemic regulation by various mechanisms like delaying gastric emptying, stimulating satiety centre in hypothalamus, thereby delaying the rate of appearance of glucose in blood and preventing post-prandial spikes in blood glucose levels [5]. The human amylin gene $I A P P$ which encodes the complete polypeptide is located in short arm of chromosome12; (12p12.1). IAPP has a proximal promoter region, exon1, intron1, exon2, intron2, exon3 (coding regionapproximately $187 \mathrm{bp}$ ) and 130 nucleotides following the stop codon [6]. Amylin is probably generated by proteolytic processing similar to that of pro-insulin and other islet pro-hormones. DNA cloning studies in humans and rats had proved that amylin is generated from a precursor called preproamylin with a signal peptide within itself which undergoes proteolytic cleavage to form a small pro-hormone-like sequence called proamylin which is further cleaved proteolytically to form mature amylin [2]. Like insulin, amylin is also secreted in response to plasma glucose by $ß$-cells, it has been studied that Insulin gene and $I A P P$ gene exhibit sequence similarity in their promoter region, so the activation of any promoter is capable of driving a activating signal to other heterologous promoter in a tissue-specific manner [7]. So an activator mutation in promoter either of gene will positively affect the transcription of other. This supports that hyperinsulinemia goes handin-hand with hyperamylinemia. Previous mutation studies on IAPP gene promoter reported $-132 \mathrm{G}>\mathrm{A}$ mutation in type 2 diabetes patients with a frequency of $0.8 \%$ in New Zealand Maori population [6], $10 \%$ in Spanish population [8], 4\% in Danish Caucasians [9].

*Corresponding author: Jayagandan Jayamani, Post Graduate Institute of Medical Education And Research, Biochemistry, Chandigarh, India, Tel: 918374084361/ 91172-2755175; E-mail: dr.jayagandan@gmail.com

Received September 30, 2013; Accepted November 19, 2013; Published November 23, 2013

Citation: Jayamani J, Prasad R, Bhansali A (2013) Identification of a Novel -99A $>T$ IAPP Gene Mutation in A North Indian Type-2-Diabetes Patient with Hypertension. J Diabetes Metab 4: 314. doi:10.4172/2155-6156.1000314

Copyright: (c) 2013 Jayamani J, et al. This is an open-access article distributed under the terms of the Creative Commons Attribution License, which permits unrestricted use, distribution, and reproduction in any medium, provided the original author and source are credited. 
Citation: Jayamani J, Prasad R, Bhansali A (2013) Identification of a Novel -99A>T IAPP Gene Mutation in A North Indian Type-2-Diabetes Patient with Hypertension. J Diabetes Metab 4: 314. doi:10.4172/2155-6156.1000314

Page 2 of 2

\begin{tabular}{|c|c|c|}
\hline Variable & Result & Reference interval \\
\hline Total cholesterol $(\mathrm{mg} / \mathrm{dL})$ & 218 & $<200$ \\
\hline Triglycerides $(\mathrm{mg} / \mathrm{dL})$ & 442.75 & $<100$ \\
\hline HDL $(\mathrm{mg} / \mathrm{dL})$ & 42.56 & $\geq 60$ \\
\hline LDL $(\mathrm{mg} / \mathrm{dL})$ & 112.31 & $<100$ \\
\hline Sodium $(\mathrm{mEq} / \mathrm{L})$ & 137 & $136-145$ \\
\hline Potassium $(\mathrm{mEq} / \mathrm{L})$ & 3.83 & $3.5-5.3$ \\
\hline Chloride $(\mathrm{mEq} / \mathrm{L})$ & 101 & $98-106$ \\
\hline Urea $(\mathrm{mg} / \mathrm{dL})$ & 17.65 & $10-50$ \\
\hline Creatinine $(\mathrm{mg} / \mathrm{dL})$ & 0.56 & $0.5-1.3$ \\
\hline Total protein $(\mathrm{g} / \mathrm{dL})$ & 7.48 & $6.4-8.3$ \\
\hline Albumin $(\mathrm{g} / \mathrm{dL})$ & 4.4 & $3.5-5.2$ \\
\hline
\end{tabular}

Table 1: Selected patient laboratory results with corresponding reference intervals.

The IAPP promoter mutation $-99 \mathrm{~A}>\mathrm{T}$ identified was not reported in any other population is a heterozygous mutation. This novel mutation produced a sequence $5^{\prime}$-ATTGG- $3^{\prime}$ in the region corresponding to -101 to -99 , the complementary sequence of this region $3^{\prime}-$ TAACC- 5 ' resembles a CAAT box. CAAT box is a distinct pattern of nucleotides with GGCCAATCT consensus sequence that occur upstream by 100 to 300 bases to the TSS (transcription start site) [10]. It is a well known fact that CAAT box are highly active in those eukaryotic genes that are tissue specific and transcribed in large amount. The $-99 \mathrm{~A}>\mathrm{T}$ mutation did not produce a CAAT box instead it created a sequence CCAAT which can be bound by CAAT box binding transcription factors (CTF) like CBP, CP-1, C/EBPa [11]. All these CTFs are well established transcription activators, their role in initiation and maintaining efficiency of eukaryotic transcription is also very well established [12]. All these facts supports that this mutation can be an adaptation for increasing the transcription of IAPP gene. Therefore we hypothesize that $-99 \mathrm{~A}>\mathrm{T}$ mutation which is present in the activator domain of $I A P P$ gene is a gain of function mutation increasing production and deposition of amyloid in islets of pancreas. Islet amyloidosis leads to B cells destruction and impaired glucose utilization, which in turn predisposed the patient for early onset Type 2 diabetes by the age of 29. The increased transcription leads to increased plasma amylin level which is capable of activating the renin-angiotensin-aldosterone system (RAAS) in kidneys by binding to amylin receptors present in the renin producing cells in juxtaglomerular apparatus [13]. The binding of amylin to its receptors can either directly release stored renin from cells or indirectly it can lead to increased conversion of prorenin to mature renin. Administration of a competitive inhibitor of amylin displaced amylin from its renal binding sites and abolished amylin induced renin activity in rats this further confirms its renal action apart from its role in carbohydrate metabolism $[13,14]$. Amylin also significantly increases sodium retention via stimulation of proximal tubular ion transport in rats [15]. This amylin mediated RAAS activation, obesity, dyslipidemia altogether lead to increased blood pressure in Type 2 diabetes patients. Altogether we hypothesize that there can be a potential role for this newly identified IAPP mutation $-99 \mathrm{~A}>\mathrm{T}$ not only in the early onset of type 2 diabetes but also its early progression to metabolic syndrome in which along with hyperinsulinemia, hypertension, hyperlipidemia, obesity, hyperamylinemia may also forms a component.

\section{Conclusion}

The novel mutation $-99 \mathrm{~A}>\mathrm{T}$ identified in our study was found in activator domain (located between -91 to -222 bases upstream of exon1) of the IAPP promoter producing a potential binding site for transcription activators like CCAAT box binding transcription factors which may lead to increased transcription of IAPP gene ultimately leading to increased islet amyloid production, deposition and $B$-cell destruction, hypertension through stimulation of RAAS.

\section{References}

1. Mosselman S, Höppener JW, Lips CJ, Jansz HS (1989) The complete islet amyloid polypeptide precursor is encoded by two exons. FEBS Lett 247: 154158

2. Cooper GJ, Day AJ, Willis AC, Roberts AN, Reid KB, et al. (1989) Amylin and the amylin gene: structure, function and relationship to islet amyloid and to diabetes mellitus. Biochim Biophys Acta 1014: 247-258.

3. Cooper GJ, Willis AC, Clark A, Turner RC, Sim RB, et al. (1987) Purification and characterization of a peptide from amyloid-rich pancreases of type 2 diabetic patients. Proc Natl Acad Sci U S A 84: 8628-8632.

4. Westermark P, Wernstedt C, Wilander E, Hayden DW, O'Brien TD, et al. (1987) Amyloid fibrils in human insulinoma and islets of Langerhans of the diabetic cat are derived from a neuropeptide-like protein also present in normal islet cells. Proc Natl Acad Sci U S A 84: 3881-3885.

5. Pittner RA, Albrandt K, Beaumont K, Gaeta LS, Koda JE, et al. (1994) Molecular physiology of amylin. J Cell Biochem 55: 19-28.

6. Poa NR, Cooper GJ, Edgar PF (2003) Amylin gene promoter mutations predispose to Type 2 diabetes in New Zealand Maori. Diabetologia 46: 574578.

7. Mosselman S, Höppener JW, de Wit L, Soeller W, Lips CJ, et al. (1990) IAPP/ amylin gene transcriptional control region: evidence for negative regulation. FEBS Lett 271: 33-36.

8. Novials A, Rodriguez-Mañas L, Chico A, El Assar M, Casas S, et al. (2007) Amylin and hypertension: association of an amylin -G132A gene mutation and hypertension in humans and amylin-induced endothelium dysfunction in rats. $J$ Clin Endocrinol Metab 92: 1446-1450.

9. Pildal J, Lajer M, Hansen SK, Almind K, Ambye L, et al. (2003) Studies of variability in the islet amyloid polypeptide gene in relation to Type 2 diabetes. Diabet Med 20: 491-494.

10. Tasanen K, Oikarinen J, Kivirikko KI, Pihlajaniemi T (1992) Promoter of the gene for the multifunctional protein disulfide isomerase polypeptide. Functional significance of the six CCAAT boxes and other promoter elements. J Biol Chem 267: 11513-11519.

11. http://www.cbil.upenn.edu/cgi-bin/tess/tess

12. Lum LS, Sultzman LA, Kaufman RJ, Linzer DI, Wu BJ (1990) A cloned human CCAAT-box-binding factor stimulates transcription from the human hsp70 promoter. Mol Cell Biol 10: 6709-6717.

13. Wookey PJ, Cao Z, Cooper ME (1998) Interaction of the renal amylin and reninangiotensin systems in animal models of diabetes and hypertension. Miner Electrolyte Metab 24: 389-399.

14. Wookey PJ, Cao Z, van Geenen RC, Voskuil M, Darby IA, et al. (1997) Increased density of renal amylin binding sites in experimental hypertension. Hypertension 30: 455-460.

15. Harris PJ, Cooper ME, Hiranyachattada S, Berka JL, Kelly DJ, et al. (1997) Amylin stimulates proximal tubular sodium transport and cell proliferation in the rat kidney. Am J Physiol 272: F13-21. 